DOI: https://doi.org/10.47405/mjssh.v6i3.724

\begin{tabular}{|c|c|}
\hline 5 & Malaysian Journal of Social Sciences and Humanities (MJSSH) \\
\hline Malaysian Journal of & Volume 6, Issue 3, March 2021 \\
\hline (Mus- SSH) & e-ISSN : 2504-8562 \\
\hline & $\begin{array}{l}\text { Journal home page: } \\
\text { www.msocialsciences.com }\end{array}$ \\
\hline
\end{tabular}

\title{
Kesan Kaedah Pembelajaran Berasaskan Multiple Document-Based Lessons Terhadap Pengekalan Penguasaan Kemahiran Pemikiran Sejarah dalam kalangan Murid Tingkatan Satu
}

\author{
M. Kaviza ${ }^{1}$ \\ ${ }_{1}^{1}$ Pusat Pengajian Pendidikan dan Bahasa Moden, Universiti Utara Malaysia (UUM) \\ Correspondence: M. Kaviza (kavizakaviza@yahoo.com)
}

\begin{abstract}
Abstrak
Kajian eksperimen dengan reka bentuk faktorial $3 \times$ X 3 ini bertujuan mengkaji kesan kaedah pembelajaran berasaskan Multiple Document-Based Lessons terhadap pengekalan penguasaan kemahiran pemikiran sejarah dalam kalangan murid. Seramai 102 orang murid Tingkatan Satu melalui teknik persampelan berkelompok terlibat dalam kajian ini. Instrumen kajian ini merupakan ujian kemahiran pemikiran sejarah yang telah dibina oleh pengkaji yang telah disahkan oleh pakar-pakar penilai serta mempunyai nilai kebolehpercayaan yang baik. Data kuantitatif dalam kajian ini telah dianalisis secara statistic deskriptif dan statistic inferensi iaitu melalui ujian SPANOVA dengan menggunakan perisian IBM SPSS versi 24. Dapatan kajian ini telah menunjukkan bahawa kaedah pembelajaran berasaskan Multiple Document-based Lessons adalah lebih berkesan berbanding dengan kaedah pembelajaran berasaskan Document-based Lessons dan kaedah pengajaran konvensional terhadap pengekalan penguasaan kemahiran pemikiran sejarah dalam kalangan murid. Implikasi kajian ini telah menyediakan sumber maklumat kepada para guru sejarah bahawa kaedah pembelajaran berasaskan Multiple Document-Based Lessons telah dibuktikan adalah lebih berpotensi dilaksanakan dalam pendidikan Sejarah selaras dengan inovasi dalam kaedah pengajaran sejarah sedia ada.
\end{abstract}

Kata kunci: kaedah pembelajaran berasaskan multiple document-based lessons, pengekalan, penguasaan, kemahiran pemikiran sejarah, murid tingkatan satu

\section{The Effect of Learning Method based on Multiple Document-Based Lessons towards the Retention of Historical Thinking Skills Acquisition among Form One Students}

\begin{abstract}
The experimental study with $3 \times 3$ factorial design aims to investigate the effect of learning method based on multiple document-based lessons towards retention of historical thinking skills acquisition among students. A total of 112 form one student's using cluster sampling technique involved in this study. The research instrument used in this study is historical thinking skills test which are developed by the researcher, has been validated by the content expert matters and has a good reliability scores, difficulty and discrimination indices. The quantitative data in this study were analyzed by SPANOVA test using IBM SPSS version 24. The findings of this study reported the learning method based on multiple document-based lessons more effective compared to learning method based on documentbased lessons and conventional method toward the retention of historical thinking skills acquisition.
\end{abstract}


The implications of this study provided information to history teachers that learning with multiple document-based lessons has proven more potential to implement in history education in line with innovations in existing history teaching methods.

Keywords: multiple document-based lessons, rentetion, historical thinking skills, form one students, acquisition

\section{Pengenalan}

Kemahiran pemikiran sejarah merupakan satu elemen yang penting dalam kerangka disiplin ilmu sejarah dalam kurikulum sejarah yang perlu ditekankan bagi menjadikan proses pembelajaran sejarah lebih dinamik dengan mendedahkan murid-murid kepada proses inkuiri yang dapat meningkatkan pemikiran kritis, analitis dan imaginatif (Pusat Perkembangan Kurikulum [PPK], 2003; 2015). Penekanan kepada penguasaan kemahiran pemikiran sejarah adalah selaras dengan matlamat Pelan Pembangunan Pendidikan Malaysia tahun 2013 hingga 2025 iaitu melaksanakan transformasi sistem pendidikan Malaysia untuk melengkapkan setiap murid dengan pelbagai pengetahuan dan kemahiran yang baharu yang diperlukan bagi merebut peluang dan cabaran abad ke-21 (Kementerian Pendidikan Malaysia [KPM], 2013). Tambahan pula, adalah tidak dapat disangkal bahawa penguasaan kemahiran pemikiran sejarah dapat dipertingkatkan berdasarkan proses analisis bukti sejarah yang konkrit dan sahih yang menjadikan murid-murid berperanan sebagai seorang ahli sejarah yang berpengalaman bagi mengemukakan sesuatu pentafsiran sejarah secara mendalam dengan membuat perbandingan, menghubungkait dan menilai semula sesuatu peristiwa sejarah antara konteks masa dahulu dan kini (Afterbach \& VanSledright, 2001; Barton \& Levistik, 2004; Culminas-Culis \& Reyes, 2016; Levistik \& Barton, 2011; VanSledright, 2002). Menyedari kepentingan penekanan kemahiran pemikiran sejarah dalam kurikulum sejarah, maka pihak PPK $(2003$; 2015) telah menyarankan lima konstruk dalam kemahiran pemikiran sejarah yang perlu dikuasai dalam kalangan murid iaitu kemahiran memahami kronologi, kemahiran meneroka bukti, kemahiran membuat interpretasi, kemahiran membuat imaginasi dan kemahiran membuat rasionalisasi.

\section{Latar Belakang Kajian}

Document based lessons merupakan strategi pembelajaran sejarah berdasarkan analisis sumber atau bahan yang membolehkan murid-murid dapat mentafsir, meneroka, menganalisis dan mensintesis pelbagai maklumat sejarah bagi meningkatkan pemahaman dan menjana proses pemikiran sejarah secara analitikal (Harris, Halvorsen \& Aponte-Martinez, 2015; Newmann, 2001; Rantala dan Vanden Berg, 2015; Reisman, 2012a, 2012b; Stromso, 2014; Stromoso, Braten, Britt \& Ferquson, 2013). Strategi pembelajaran berasaskan Document based lessons adalah berupaya untuk mewujudkan ruang persekitaran pembelajaran yang aktif dengan membolehkan murid-murid dapat membuat interpretasi dan tafsiran dengan menggunakan bahan-bahan, di samping dapat membolehkan murid-murid berperanan sebagai seorang ahli sejarah yang professional semasa proses pembelajaran sejarah (Nieuwenhuyse, Roose, Wils, Depaepe, Verschaffel, 2017; Nye, Hughes-Warrington, Roe, Russell, Deacon, \& Kiem, 2011; Sandwell, 2008). Hal ini bertepatan dengan manfaat dan potensi penggunaan sumber-sumber sejarah dalam proses pengajaran dan pembelajaran sejarah seperti yang diperincikan oleh pengkaji Barton (2018) dan Hazri Jamil (2003) dan berdasarkan kupasan kajian-kajian lepas yang dilakukan oleh pengkaji dalam kajian ini (Kaviza, 2020) iaitu membolehkan murid-murid dapat membuat perbandingan maklumat antara sumber-sumber, murid-murid berupaya untuk berfikir secara rasional di sebalik berlakunya sesuatu peristiwa sejarah, murid-murid berupaya untuk menggambarkan semula sesuatu rentetan peristiwa sejarah yang berlaku dengan sokongan bahan bukti, murid-murid berupaya untuk meningkatkan minat belajar sejarah apabila mereka berpeluang untuk memainkan peranan sebagai seorang ahli sejarah dan murid-murid berupaya untuk meningkatkan kebolehan dan daya intelektual secara kritis dan analitis melalui proses pengkajian dan pentafsiran sejarah yang mendalam. Pelaksanaan kaedah pembelajaran berasaskan Document based lessons adalah berlandaskan kepada langkah-langkah yang dipelopori oleh Abby Reisman dalam kajiannya (Reisman, 2012a; 
2012b) yang terdiri daripada fasa pengetahuan sedia ada, fasa inkuiri sejarah dan fasa perbincangan. Pelaksanaan tatacara Document based lessons secara sistematik dan teratur dapat membentuk suasana pembelajaran secara aktif yang dapat menggalakkan murid-murid untuk membuat proses analisis secara, sistematik dan teratur (Reisman, 2012a; 2012b) seperti yang disarankan dalam kurikulum sejarah.

Adalah tidak dinafikan bahawa penguasaan kemahiran pemikiran sejarah dalam kalangan murid sekolah menengah dilaporkan masih berada pada tahap sederhana (Ling, Mona Massod \& Siti Hawa Abdullah, 2016; Renuka Ramakrishnan, Norizan Esa \& Siti Hawa Abdullah, 2014; Rosy Talin, 2016; Kaviza, 2019). Hal ini demikian kerana murid-murid tidak dapat menjawab soalan-soalan pemikiran sejarah aras tinggi yang memerlukan penjelasan dan penghuraian jawapan berdasarkan fakta, huraian dan contoh yang konkrit. Kelemahan penguasaan kemahiran pemikiran sejarah adalah disebabkan oleh amalan kaedah pengajaran yang berpusatkan guru dan penghafalan maklumat sejarah yang telah mengehadkan proses pemahaman dan pemikiran sejarah dan menimbulkan kebosanan belajar dalam kalangan murid (Fitzegerald, 2009; Foster \& Crawford, 2006; Kobrin, 1996; Ramoroka \& Engelbrecht, 2015; Sharp \& Ammert, 2017). Rentetan daripada itu, bagi menyahut perubahan dalam amalan kaedah pengajaran yang berpusatkan murid yang membolehkan murid dilengkapi dengan pelbagai maklumat dan kemahiran pemikiran kritis yang berguna pada masa hadapan (Abdul Razaq Ahmad, 2014; Lezah @ Lejah Kiamsin \& Rosy Talin, 2018; Ummadevi Suppiah, 2018), maka kaedah pembelajaran Document-Based Lessons adalah antara strategi pembelajaran yang berpotensi dilaksanakan dalam proses pembelajaran sejarah dalam membentuk persekitaran pembelajaran yang lebih bermakna dalam kalangan murid. Hal ini demikian kerana pelaksanaan kaedah pembelajaran Document-Based Lessons dilaporkan telah memaparkan impak positif dari aspek penjanaan pemahaman sejarah, peningkatan kemahiran literasi bacaan, perubahan peranan dan minat terhadap proses pembelajaran sejarah, pemupukan kemahiran berfikir aras tinggi, penaakulan sejarah, penulisan hujah sejarah, kemahiran belajar dan penglibatan aktif murid dalam pembelajaran (Macedo-Rouet, Braasch, Britt \& Rouet, 2013; Neuman, Gilberston \& Hutton, 2014; Nokes, Dole \& Hacker, 2007; Reisman, 2012a, 2012b; Veijola \& Rantala, 2018; Nokes, 2014, 2017; Rouet-Franqois, Favart, Britt \& Ferfetti, 1997; Patterson, Lucas \& Kithinji, 2012; Stovel, 2000; Wiley \& Voss, 1999; Linquist \& Long, 2011).

\section{Pernyataan Masalah}

Walau bagaimanapun, adalah tidak disangkal bahawa pengkaji kajian ini telah mengkaji tahap penjanaan aplikasi strategi kemahiran pemikiran sejarah melalui aktiviti analisis sumber-sumber dokumen teks sejarah dari perspektif murid berbeza tahap pemikiran kritis yang telah diukur melalui soal selidik (Kaviza, 2019). Namun, sejauh manakah pengekalan bagi penguasaan kemahiran pemikiran sejarah melalui soalan-soalan pemikiran sejarah adalah perlu dikaji walaupun dalam kajian kedoktoran yang telah dijalankan oleh Renuka Ramakrishnan (2015) telah melaporkan bahawa penggunaan sumber digital sejarah adalah berkesan terhadap penguasaan kemahiran pemikiran sejarah dalam kalangan murid Tingkatan Empat. Perkara ini telah mencadangkan terdapat suatu keperluan untuk mengkaji keberkesanan pengekalan penguasaan kemahiran pemikiran sejarah dalam kalangan murid, khususnya murid Tingkatan Satu yang masih berada dalam era transisi dalam proses pembelajaran sejarah sebagai mata pelajaran teras di sekolah menengah dan sebagai persediaan untuk membimbing murid terhadap penguasaan kemahiran pemikiran sejarah sejak dari peringkat awal lagi. Tambahan pula, keperluan untuk menentukan keberkesanan pengekalan penguasaan kemahiran pemikiran sejarah untuk suatu tempoh jangka masa yang panjang juga turut telah diutarakan dalam dapatan kajian-kajian lepas (Adinopoulou \& Sampson, 2017; Reisman 2012a; Olwell \& Stevens, 2015; Renuka Ramakrishnan, Norizan Esa \& Siti Hawa Abdullah, 2014). Sungguhpun begitu, berdasarkan penelitian pengkaji lagi terhadap kajian-kajian lepas telah menunjukkan bahawa terdapat sedikit kekurangan terhadap pelaksanaan kaedah pembelajaran Document-Based Lessons (Reisman, 2012a, 2021b; Nokes, 2014; Kaviza, 2019) iaitu dari segi pengingtegrasian pendekatan kepelbagaian sumber iaitu kombinasi analisis sumber teks dengan sumber visual, audio, video, imej dan sebagainya yang bersifat multimodal yang bertujuan untuk meningkatkan pemerolehan maklumat sejarah dengan lebih meluas lagi (Britt \& Rouet, 2011; Donnelly, 2018; Merkt, Werner, \& Wagne, 2017; Reisman, 2012b). Pengingtegrasian pendekatan kepelbagaian sumber dalam kaedah pembelajaran Document-Based 
DOI: https://doi.org/10.47405/mjssh.v6i3.724

Lessons telah diklasifikasikan oleh pengkaji kajian ini sebagai kaedah pembelajaran Multiple Document-Based Lessons. Justeru, terdapat satu keperluan kepada pengkaji dalam kajian ini untuk mengkaji kesan kaedah pembelajaran Multiple Document-Based Lessons terhadap pengekalan penguasaan kemahiran pemikiran sejarah dalam kalangan murid.

\section{Tujuan Kajian}

Tujuan kajian ini adalah untuk mengkaji kesan kaedah pembelajaran berasaskan Multiple Documentbased Lessons terhadap pengekalan penguasaan kemahiran pemikiran sejarah dalam kalangan murid.

\section{Objektif Kajian}

Mengenal pasti sama ada kaedah pembelajaran berasaskan Multiple Document-based Lessons lebih berkesan berbanding dengan kaedah pembelajaran berasaskan Document-based Lessons dan kaedah pengajaran konvensional terhadap pengekalan penguasaan kemahiran pemikiran sejarah berdasarkan waktu ujian iaitu ujian pra, ujian pasca dan ujian pasca lanjutan.

\section{Hipotesis Kajian}

$\mathrm{H}_{01}$ : Tidak terdapat kesan utama kaedah pengajaran (kaedah pembelajaran berasaskan Multiple Document-based Lessons, kaedah pembelajaran berasaskan Document-based Lessons dan kaedah pengajaran konvensional) yang signifikan terhadap pengekalan penguasaan kemahiran pemikiran sejarah.

$\mathrm{H}_{02}$ : Tidak terdapat kesan utama waktu ujian (ujian pra, ujian pasca dan ujian pasca lanjutan) yang signifikan terhadap pengekalan penguasaan kemahiran pemikiran sejarah.

$\mathrm{H}_{03}$ : Tidak terdapat kesan interaksi antara kaedah pengajaran dan waktu ujian yang signifikan terhadap pengekalan penguasaan kemahiran pemikiran sejarah.

\section{Metodologi Kajian}

Kajian eksperimental dengan reka bentuk faktorial 3 X 3 telah digunakan dalam kajian ini untuk menentukan sama ada terdapat kesan utama dan kesan interaksi antara waktu ujian (ujian pra, ujian pasca dan ujian pasca lanjutan) dan kaedah pengajaran (kumpulan kaedah pembelajaran berasaskan Multiple Document-based Lessons, kumpulan kaedah pembelajaran berasaskan Document-based Lessons and kumpulan kaedah pengajaran konvensional) terhadap pengekalan penguasaan kemahiran pemikiran sejarah (Campbell \& Stanley, 1963; Cook \& Campbell, 1979). Seramai 102 orang murid Tingkatan Satu yang ditentukan berdasarkan teknik persampelan berkelompok telah terlibat dalam kajian ini (Uma Sekaran \& Bougie, 2013). Instrumen kajian ini merupakan ujian penguasaan kemahiran pemikiran sejarah yang terdiri daripada 20 item subjektif yang telah dibina oleh pengkaji, yang telah disahkan konstruknya oleh pakar penilai yang berpengalaman dan mempunyai nilai kebolehpercayaan (nilai pekali koefisien Alpha Cronbach=0.95), nilai indeks kesukaran (antara nilai 0.31 hingga 0.67 ) dan nilai indeks diskriminasi (antara nilai 0.55 hingga 0.78) yang boleh diterima bagi tujuan kajian ini (Nunnally \& Berstein, 1994; Kapplan \& Saccuzzo, 2009; Crocker \& Algina, 2008). Data kuantittaif dalam kajian ini telah dianalisis secara statistik deskriptif dan inferensi iaitu Ujian SPANOVA telah digunakan untuk membandingkan dua jenis variabel bebas yang salah satu variabelnya terdiri daripada data pengukuran berulang dan kaedah pengajaran terhadap variabel bersandar dalam kajian ini (Field, 2013, 2016). Pelaksanaan kaedah pembelajaran berasaskan Multiple Document-based Lessons dan kaedah pembelajaran berasaskan Document-based Lessons adalah berdasarkan langkahlangkah dalam kaedah pembelajaran berasaskan Document-based Lessons yang telah dipelopori oleh Abby Reisman (Reisman 2012a, 2012b) dan kebenaran menggunakan kerangka langkah-langkah kaedah pembelajaran tersebut juga telah diperolehi daripada pelopornya secara atas talian. Modul 
pengajaran dan pembelajaran telah dibangunkan oleh pengkaji bagi melaksanakan intervensi kajian ini bagi topik Tamadun Awal Dunia. Murid-murid ditadbir ujian pra sebelum intervensi dimulakan bagi menentukan kesetaraan murid terlebih dahulu sebelum pengukuran dilakukan, diikuti dengan ujian pasca sejurus selepas tamatnya intervensi yang dijalankan serta ujian pasca lanjutan selepas tempoh masa sebulan tamatnya intervensi dalam kajian ini.

\section{Dapatan Kajian}

Walaupun nilai ujian Box's $M$ yang tidak signifikan $[F(12,47243.87)=0.62, p=0.83]$ telah menunjukkan bahawa kovarians antara kumpulan-kumpulan adalah sama (Green \& Salkind, 2017), namun ujian Multivariate bagi min skor pengekalan penguasaan kemahiran pemikiran sejarah tidak dapat dijalankan dalam kajian ini. Hal ini demikian kerana dapatan ujian Kesferaan Mauchly's $W$ bagi min skor pengekalan penguasaan kemahiran pemikiran sejarah adalah signifikan $\left[x^{2}(2)=28.51, p=0.00\right]$ yang menunjukkan bahawa andaian kesferaan (Sphericity Assumed) adalah tidak dipatuhi. Maka, penyelarasan nilai darjah kebebasan ( $d f$ ) perlu dilakukan dengan menggunakan nilai Epsilon HuynhFeldt agar dapat mengawal ralat jenis 1 dalam kajian ini (Hair, Black, Babin \& Anderson 2014).

Berdasarkan nilai ujian Levene's yang tidak signifikan bagi min skor ujian pra $[F(2,99)=0.18, p=0.84]$, min skor ujian pasca $[F(2,99)=0.22, p=0.80]$ dan min skor ujian pasca lanjutan $[F(2,99)=0.87$, $p=0.42]$ terhadap pengekalan penguasaan kemahiran pemikiran sejarah dalam kajian ini yang menunjukkan bahawa varians antara ketiga-tiga kaedah pengajaran tersebut adalah setara (Green \& Salkind, 2017), maka dapatan ujian Univariate bagi kesan variabel antara subjek pada Jadual 1 telah menunjukkan bahawa terdapat perbezaan min skor pengekalan penguasaan kemahiran pemikiran sejarah yang signifikan antara kumpulan Multiple Document-based Lessons, kumpulan Documentbased Lessons dan kumpulan kaedah pengajaran konvensional $\left[F(2,99)=308.04, p=0.00, \eta_{\mathrm{p}}{ }^{2}=0.86\right]$ dengan kesan saiz adalah besar (Gray \& Kinnear, 2012).

Jadual 1: Keputusan Ujian Univariate bagi Kesan Variabel Antara Subjek bagi Min Skor Pengekalan penguasaan Kemahiran Pemikiran Sejarah

\begin{tabular}{lcccccc}
\hline Kesan & $\begin{array}{c}\text { Jumlah } \\
\text { kuasa } \\
\text { Dua }\end{array}$ & $\boldsymbol{d f}$ & $\begin{array}{c}\text { Min } \\
\text { Kuasa } \\
\text { Dua }\end{array}$ & $\boldsymbol{F}$ & $\boldsymbol{p}$ & $\mathbf{\eta}_{\mathbf{p}}{ }^{2}$ \\
\hline Pintasan & 77107.84 & 1 & 77107.84 & 3374.4 & 0.00 & 0.97 \\
Kaedah pengajaran & 14077.80 & 2 & 7038.90 & 308.04 & 0.00 & 0.86 \\
Ralat & 2262.18 & 99 & 22.85 & & & 8 \\
\hline
\end{tabular}

Tambahan pula, perbezaan antara pasangan kaedah pengajaran terhadap min skor pengekalan penguasaan kemahiran pemikiran sejarah dalam kajian ini juga telah ditunjukkan melalui ujian perbandingan pelbagai Post Hoc Sidak dan dapatan ujian tersebut pada Jadual 2 telah menunjukkan bahawa:

(a) Kumpulan Multiple Document-based Lessons mendapat min skor pengekalan penguasaan kemahiran pemikiran sejarah yang lebih tinggi secara signifikan berbanding dengan kumpulan Document-based Lessons (perbezaan min kumpulan Multiple Document-based Lessons-kumpulan Document-based Lessons $=9.44, \quad p=0.00$ ) dan kumpulan kaedah pengajaran konvensional (perbezaan min kumpulan Multiple Document-based Lessons kumpulan kaedah pengajaran konvensional $=28.05, p=0.00$ ).

(b) Kumpulan eksperimen kedua mendapat min skor pengekalan penguasaan kemahiran pemikiran sejarah yang lebih rendah berbanding dengan kumpulan Multiple Documentbased Lessons (perbezaan min kumpulan Document-based Lessons-kumpulan Multiple Document-based Lessons $=-9.44, p=0.00$ ) dan min skor pengekalan penguasaan kemahiran pemikiran sejarah yang lebih tinggi secara signifikan daripada kumpulan kaedah pengajaran 
konvensional (perbezaan min kumpulan Document-based Lessons-kumpulan kaedah pengajaran konvensional $=18.60, p=0.00$ ).

(c) Kumpulan kaedah pengajaran konvensional mendapat min skor pengekalan penguasaan kemahiran pemikiran sejarah yang lebih rendah berbanding dengan kumpulan Multiple Document-based Lessons (perbezaan min kumpulan kaedah pengajaran konvensional kumpulan Multiple Document-based Lessons $=-28.05, p=0.00$ ) dan kumpulan eksperimen kedua (perbezaan min kumpulan kaedah pengajaran konvensional-kumpulan Documentbased Lessons $=-18.60, p=0.00)$.

Justeru, hipotesis kajian $\mathrm{H}_{\mathrm{ol}}$ telah berjaya ditolak iaitu terdapat kesan utama kaedah pengajaran yang signifikan terhadap min skor pengekalan penguasaan kemahiran pemikiran sejarah. Oleh itu, dapat dirumuskan bahawa kumpulan Multiple Document-based Lessons telah menunjukkan min skor pengekalan penguasaan kemahiran pemikiran sejarah yang lebih tinggi berbanding dengan kumpulan Document-based Lessons dan kumpulan kaedah pengajaran konvensional dalam kajian ini.

Jadual 2: Keputusan Ujian Perbandingan Pelbagai Post Hoc Sidak Untuk Min Skor Pengekalan penguasaan Kemahiran Pemikiran Sejarah Berdasarkan Kaedah Pengajaran

\begin{tabular}{llccccc}
\hline Kumpulan & Kumpulan & $\begin{array}{c}\text { Perbezaan } \\
\text { Min }\end{array}$ & $\begin{array}{c}\text { Ralat } \\
\text { Piawai }\end{array}$ & $\boldsymbol{p}$ & \multicolumn{2}{c}{$\begin{array}{c}\text { 95\% selang keyakinan } \\
\text { bagi perbezaan } \\
\text { Bawah }\end{array}$} \\
& & & & & Atas \\
\hline Eksp 1 & Eksp 2 & $9.44^{*}$ & 1.17 & 0.00 & 6.61 & 12.28 \\
& Kawalan & $28.05^{*}$ & 1.15 & 0.00 & 25.25 & 30.84 \\
Eksp 2 & Eksp 1 & $-9.44^{*}$ & 1.17 & 0.00 & -12.28 & -6.61 \\
& Kawalan & $18.60^{*}$ & 1.16 & 0.00 & 15.79 & 21.42 \\
Kawalan & Eksp 1 & $-28.05^{*}$ & 1.15 & 0.00 & -30.84 & -25.25 \\
& Eksp 2 & $-18.60^{*}$ & 1.16 & 0.00 & -21.42 & -15.79 \\
\hline
\end{tabular}

Nota: (Eksp 1= Eksperimen pertama, Eksp 2= Eksperimen kedua)

Berdasarkan estimated marginal means

*Pada aras kesignifikan $(p=0.05)$

Seterusnya, oleh kerana dapatan ujian Kesferaan Mauchly's $W$ bagi min skor pengekalan penguasaan kemahiran pemikiran sejarah adalah signifikan $\left[x^{2}(2)=28.51, p=0.00\right]$ yang telah menunjukkan bahawa andaian kesferaan (Sphericity Assumed) adalah tidak dipatuhi, maka penyelarasan nilai darjah kebebasan $(d f)$ telah dilakukan dalam kajian ini dengan menggunakan nilai Epsilon Huynh-Feldt dan dapatan ujian tersebut pada Jadual 3 telah menunjukkan bahawa terdapat kesan utama waktu ujian yang signifikan $\left[F(1.65,163.52)=312.17, p=0.00, \eta_{\mathrm{p}}{ }^{2}=0.76\right]$ terhadap min skor pengekalan penguasaan kemahiran pemikiran sejarah dengan kesan saiz adalah besar (Gray \& Kinnear, 2012).

Jadual 3: Keputusan Ujian Univariate bagi Kesan Variabel Dalam Subjek bagi Min Skor Pengekalan penguasaan Kemahiran Pemikiran Sejarah

\begin{tabular}{llcccccc}
\hline Kesan & Jumlah & $\begin{array}{c}\text { df } \\
\text { kuasa Dua } \\
\text { Jenis III }\end{array}$ & & $\begin{array}{c}\text { Kuasa } \\
\text { dua min }\end{array}$ & $\boldsymbol{F}$ & $\boldsymbol{p}$ & $\mathbf{\eta}_{\mathbf{p}}{ }^{\mathbf{2}}$ \\
\hline Waktu & Sphericity Assumed & 48422.17 & 2 & 24211.08 & 312.17 & 0.00 & 0.76 \\
& Greenhouse-Geisser & 48422.17 & 1.60 & 30323.30 & 312.17 & 0.00 & 0.76 \\
& Huynh-Feldt & 48422.17 & 1.65 & 29316.69 & 312.17 & 0.00 & 0.76 \\
& Lower-bound & 48422.17 & 1.00 & 48422.16 & 312.17 & 0.00 & 0.76 \\
Waktu* & Sphericity Assumed & 21439.86 & 4 & 5359.96 & 69.11 & 0.00 & 0.58 \\
Kaedah & Greenhouse-Geisser & 21439.86 & 3.19 & 6713.12 & 69.11 & 0.00 & 0.58 \\
& Huynh-Feldt & 21439.86 & 3.30 & 6490.27 & 69.11 & 0.00 & 0.58 \\
Ralat & Lower-bound & 21439.86 & 2.00 & 10719.93 & 69.11 & 0.00 & 0.58 \\
& Sphericity Assumed & 15356.57 & 198 & 77.56 & & & \\
& Greenhouse-Geisser & 15356.57 & 158.09 & 97.14 & & & \\
\hline & Huynh-Feldt & 15356.57 & 163.52 & 93.91 & & & \\
\hline
\end{tabular}


Selain itu, perbezaan antara pasangan waktu ujian terhadap min skor pengekalan penguasaan kemahiran pemikiran sejarah juga telah ditunjukkan dalam kajian ini melalui ujian perbandingan pelbagai Post Hoc Sidak dan dapatan ujian tersebut pada Jadual 4 telah menunjukkan bahawa:

(a) Min skor pengekalan penguasaan kemahiran pemikiran sejarah dalam ujian pra adalah lebih rendah secara signifikan berbanding dengan ujian pasca (perbezaan min ujian pra-ujian pasca $=-26.89, p=0.00$ ) dan ujian pasca lanjutan (perbezaan min ujian pra-ujian pasca lanjutan=-26.49, $p=0.00$ ).

(b) Min skor pengekalan penguasaan kemahiran pemikiran sejarah dalam ujian pasca adalah lebih tinggi secara signifikan berbanding dengan min skor ujian pra (perbezaan min ujian pasca-ujian pra $=26.89, p=0.00$ ) dan min skor pengekalan penguasaan kemahiran pemikiran sejarah adalah lebih tinggi secara tidak signifikan berbanding dengan min skor ujian pasca lanjutan (perbezaan min ujian pasca - ujian pasca lanjutan $=0.39, p=0.99$ ).

(c) Min skor pengekalan penguasaan kemahiran pemikiran sejarah dalam ujian pasca lanjutan adalah lebih tinggi secara signifikan berbanding dengan min skor ujian pra (perbezaan min ujian pasca lanjutan-ujian pra $=26.49, p=0.00$ ) dan min skor pengekalan penguasaan kemahiran pemikiran sejarah adalah lebih rendah secara tidak signifikan berbanding dengan min skor ujian pasca (perbezaan min ujian pasca lanjutan-ujian pasca $=-0.39, p=0.99$ ).

Justeru, hipotesis kajian $\mathrm{H}_{02}$ telah berjaya ditolak iaitu terdapat kesan utama waktu ujian yang signifikan terhadap min skor bagi pengekalan penguasaan kemahiran pemikiran sejarah. Oleh itu, dapat dirumuskan bahawa terdapat min skor pengekalan penguasaan kemahiran pemikiran sejarah adalah lebih tinggi dalam ujian pasca berbanding dengan ujian pra dan ujian pasca lanjutan.

Jadual 4: Keputusan Ujian Perbandingan Pelbagai Post Hoc Sidak Untuk Min Skor Pengekalan penguasaan Kemahiran Pemikiran Sejarah berdasarkan Waktu Ujian

\begin{tabular}{llccccc}
\hline $\begin{array}{c}\text { I } \\
\text { Waktu ujian }\end{array}$ & $\begin{array}{c}\text { J } \\
\text { Waktu } \\
\text { ujian }\end{array}$ & $\begin{array}{c}\text { Perbezaan } \\
\text { Min }\end{array}$ & $\begin{array}{c}\text { Ralat } \\
\text { Piawai }\end{array}$ & $\boldsymbol{p}$ & \multicolumn{2}{c}{$\begin{array}{c}\text { 95\% selang keyakinan } \\
\text { bagi perbezaan } \\
\text { Aawah }\end{array}$} \\
\hline \multirow{2}{*}{ Pra } & Pasca & $-26.89^{*}$ & 1.08 & 0.00 & -29.50 & -24.28 \\
\multirow{3}{*}{ Pasca } & Lanjutan & $-26.49^{*}$ & 1.06 & 0.00 & -29.07 & -23.92 \\
& Pra & $26.89^{*}$ & 1.08 & 0.00 & 24.28 & 29.50 \\
& Lanjutan & 0.39 & 1.51 & 0.99 & -3.28 & 4.07 \\
& Pra & $26.49^{*}$ & 1.06 & 0.00 & 23.92 & 29.07 \\
& Pasca & -0.39 & 1.51 & 0.99 & -4.07 & 3.28 \\
\hline
\end{tabular}

Berdasarkan estimated marginal means

*Pada aras kesignifikan $(p=0.05)$

Selain itu, oleh sebab keputusan ujian Univariate bagi kesan variabel dalam subjek pada Jadual 3 telah menunjukan terdapat kesan interaksi antara waktu ujian dan kaedah pengajaran yang signifikan $\left[F(3.30,163.52)=69.11, p=0.00, \eta_{\mathrm{p}}{ }^{2}=0.58\right]$ terhadap min skor pengekalan penguasaan kemahiran pemikiran sejarah dengan kesan saiz adalah besar (Gray \& Kinnear, 2012), maka, dapat dirumuskan bahawa waktu ujian bukan sahaja mempengaruhi min skor pengekalan penguasaan kemahiran pemikiran sejarah secara berasingan, malah interaksinya dengan kaedah pengajaran adalah didapati turut memberi kesan kepada min skor pengekalan penguasaan kemahiran pemikiran sejarah dalam kajian ini. Dapatan ini dapat disokong dengan keputusan ujian Within-Subjects Contrasts pada Jadual 5 yang telah menunjukkan bahawa:

(a) Terdapat perbezaan yang signifikan antara pasangan fasa 1 (ujian pra) dan fasa 2 (ujian pasca) $\left[F(1,99)=626.11, p=0.00, \eta_{\mathrm{p}}{ }^{2}=0.86\right]$ terhadap min skor pengekalan penguasaan kemahiran pemikiran sejarah dengan kesan saiz adalah besar (Gray \& Kinnear, 2012).

(b) Tidak terdapat perbezaan yang signifikan antara pasangan fasa 2 (ujian pasca) dan fasa 3 (ujian pasca lanjutan) $\left[F(1,99)=0.07, p=0.80, \eta_{\mathrm{p}}{ }^{2}=0.01\right]$ terhadap min skor pengekalan 
penguasaan kemahiran pemikiran sejarah dengan kesan saiz adalah kecil (Gray \& Kinnear, 2012).

(c) Terdapat kesan interaksi yang signifikan antara waktu ujian dan kaedah pengajaran bagi pasangan fasa 1 (ujian pra) dan fasa 2 (ujian pasca) $\left[F(2,99)=120.27, p=0.00, \eta_{\mathrm{p}}{ }^{2}=0.71\right]$ terhadap min skor pengekalan penguasaan kemahiran pemikiran sejarah dengan kesan saiz adalah besar (Gray \& Kinnear, 2012).

(d) Tidak terdapat kesan interaksi yang signifikan antara waktu ujian dan kaedah pengajaran bagi pasangan fasa 2 (ujian pasca) dan fasa 3 (ujian pasca lanjutan) $[F(2,99)=0.92, p=0.40$, $\left.\eta_{\mathrm{p}}{ }^{2}=0.02\right]$ terhadap min skor pengekalan penguasaan kemahiran pemikiran sejarah dengan kesan saiz adalah kecil (Gray \& Kinnear, 2012).

Jadual 5: Keputusan Ujian Within-Subjects Contrasts bagi Min Skor Pengekalan penguasaan Kemahiran Pemikiran Sejarah

\begin{tabular}{lccccccc}
\hline Sumber & Waktu ujian & $\begin{array}{c}\text { Jumlah kuasa } \\
\text { Dua Jenis III }\end{array}$ & $\boldsymbol{d f}$ & $\begin{array}{c}\text { Kuasa } \\
\text { dua min }\end{array}$ & $\boldsymbol{F}$ & $\boldsymbol{p}$ & $\boldsymbol{\eta}_{\mathbf{p}}{ }^{2}$ \\
\hline Waktu & Fasa 1 vs Fasa 2 & 73696.76 & 1 & 73696.76 & 626.11 & 0.00 & 0.86 \\
& Fasa 2 vs Fasa 3 & 15.81 & 1 & 15.81 & 0.07 & 0.80 & 0.01 \\
Waktu* & Fasa 1 vs Fasa 2 & 28312.66 & 2 & 14156.33 & 120.27 & 0.00 & 0.71 \\
kaedah & Fasa 2 vs Fasa 3 & 428.59 & 2 & 214.29 & 0.92 & 0.40 & 0.02 \\
Ralat & Fasa 1 vs Fasa 2 & 11652.92 & 99 & 117.71 & & & \\
& Fasa 2 vs Fasa 3 & 23070.43 & 99 & 233.04 & & & \\
\hline
\end{tabular}

Justeru, hipotesis kajian $\mathrm{H}_{03}$ telah berjaya ditolak iaitu terdapat kesan interaksi antara kaedah pengajaran dan waktu ujian yang signifikan terhadap pengekalan penguasaan kemahiran pemikiran sejarah. Sungguhpun begitu, bagi menentukan perbezaan kumpulan kaedah pengajaran berdasarkan waktu ujian yang lebih berkesan dalam kajian ini, maka pengkaji telah meneliti graf plot profil pada Rajah 1 yang menunjukkan bahawa min skor pada ujian pasca bagi kumpulan Multiple Documentbased Lessons adalah lebih tinggi dan telah kekal pada ujian pasca lanjutan walaupun setelah tamatnya tempoh rawatan berbanding dengan kumpulan Document-based Lessons dan kumpulan kaedah pengajaran dalam kajian ini. Maka, dapat disimpulkan bahawa kaedah pembelajaran berasaskan Multiple Document-based Lessons adalah lebih berkesan terhadap pengekalan penguasaan kemahiran pemikiran sejarah berbanding dengan kaedah pembelajaran berasaskan Document-based Lessons dan kaedah pengajaran konvensional dalam kalangan murid.

\section{Rajah 1: Graf Plot Profil}

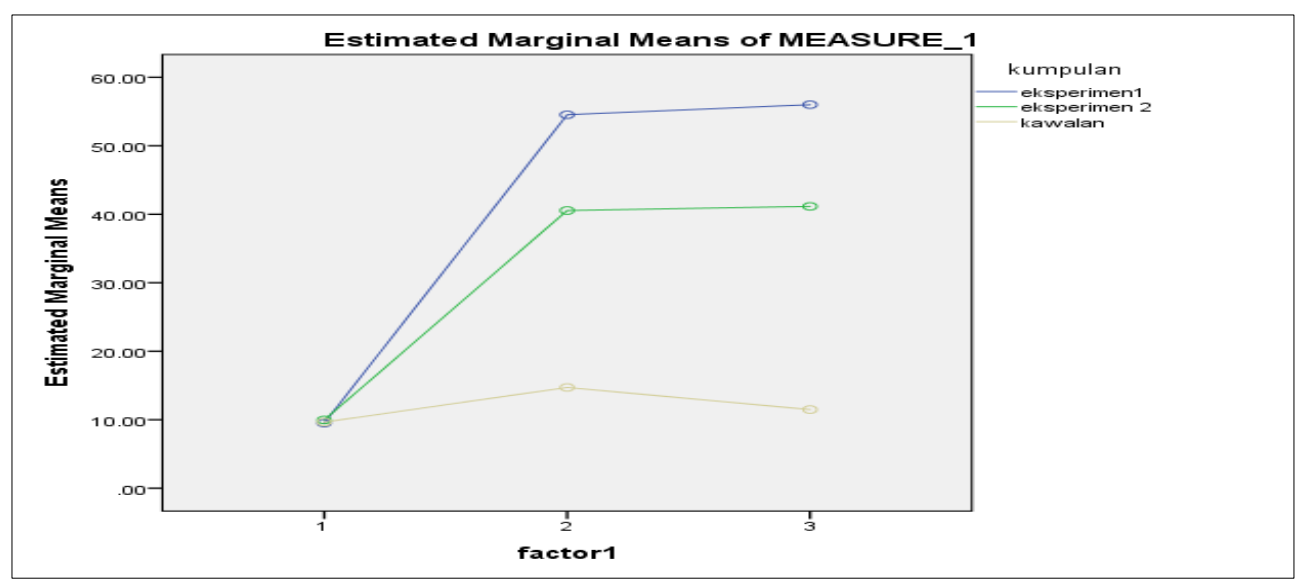

\section{Perbincangan Kajian}

Dapatan kajian ini yang telah melaporkan bahawa pembelajaran berasaskan Document-based Lessons adalah berkesan secara signifikan terhadap pengekalan penguasaan kemahiran pemikiran sejarah dalam 
kalangan murid. Hal ini disebabkan oleh pelaksanaan pembelajaran berasaskan Document-based Lessons dan penggunaan pendekatan kepelbagaian sumber yang telah diperkenalkan sebagai langkah inovasi kepada kaedah pengajaran konvensional yang menjadi antara faktor penyumbang kepada pengekalan penguasaan kemahiran pemikiran sejarah yang lebih baik dalam kalangan murid. Penggunaan pendekatan kepelbagaian sumber dalam pembelajaran berasaskan Document-based Lessons iaitu melalui Multiple Document-based Lessons yang melibatkan kombinasi antara sumber teks dengan sumber visual, video, audio dan sebagainya adalah berpotensi untuk mengekalkan penguasaan pemikiran sejarah yang kritis dan analitik seperti yang diterangkan dalam Model Kemahiran Pemikiran Sejarah (Wineburg, 2001) yang dapat menggalakkan proses analisis sumber sejarah dan dapat mengubah peranan murid sebagai seorang ahli sejarah yang professional dalam membuat sesuatu tafsiran sejarah secara komprehensif.

Walau bagaimanapun, murid yang menjalani pembelajaran berasaskan Multiple Document-based Lessons adalah berkesan untuk mengekalkan penguasaan kemahiran pemikiran sejarah yang lebih baik berbanding dengan murid yang menjalani pembelajaran berasaskan Document-based Lessons adalah disebabkan oleh kebolehan murid untuk membuat suatu gambaran dan pentafsiran sejarah yang menyeluruh dengan menganalisis sumber teks, visual, audio, video dan sebagainya. Hal ini didapati berbeza dengan murid yang menjalani pembelajaran berasaskan Document-based Lessons yang gagal untuk menggambarkan sesuatu situasi peristiwa sejarah yang berlaku atau kehidupan masyarakat masa lampau secara naratif dan pendapat ini adalah konsisten dengan pendapat Neumann et al (2014) yang menjelaskan bahawa maklumat daripada sumber teks sahaja tidak berupaya untuk membuat hubung kait antara satu peristiwa sejarah dengan satu peristiwa sejarah yang lain yang menyebabkan proses pengkajian sejarah adalah bersifat setempat sahaja tanpa melihat daripada konteks pengkajian yang berbeza dari segi lokasi dan tempat.

Dengan berlandaskan pada Teori Keluwesan Kognitif (Spiro, Coulson, Feltovisch \& Anderson, 1988; Spiro \& Jehng, 1990), murid-murid yang menjalani pembelajaran berasaskan Multiple Documentbased Lessons telah mempamerkan pengekalan penguasaan kemahiran pemikiran sejarah yang lebih baik disebabkan oleh penggunaan pelbagai jenis sumber yang dapat menstrukturkan semula maklumat yang diperolehi dalam konteks pembelajaran sejarah yang luwes dan fleksibel bagi membantu pembinaan dan pengukuhan sesuatu maklumat yang hendak dikuasai oleh murid-murid. Pengekalan yang berkesan terhadap penguasaan kemahiran pemikiran sejarah dalam kalangan murid yang menjalani pembelajaran berasaskan Multiple Document-based Lessons dalam kajian ini adalah selaras dengan dapatan kajian Greene, Bolick dan Robertson (2010) yang menggunakan bahan pembelajaran bersifat hypermedia dan kajian Kelly et al. (2019) yang menggunakan sumber teks berita daripada media sosial dalam menjana kemahiran pemikiran sejarah secara terarah kendiri dalam kalangan murid sekolah menengah yang berumur antara 12 hingga 18 tahun.

Sungguhpun begitu, murid yang menjalani pembelajaran berasaskan Multiple Document-based Lessons dan murid yang mengikuti pembelajaran berasaskan Document-based Lessons dapat mengekalkan penguasaan kemahiran pemikiran sejarah yang lebih baik berbanding dengan murid yang menjalani kaedah pengajaran konvensional walaupun selepas tamatnya rawatan yang diberikan dalam kajian ini adalah berlandaskan kepada Teori Pemprosesan Maklumat (Atkinson \& Shiffrin, 1968; 1971) yang telah menjelaskan bahawa maklumat yang diperolehi daripada penganalisaan sumber sejarah secara mendalam telah membolehkan murid-murid mampu untuk memproses maklumat tersebut sehingga pada tahap ingatan jangka panjang. Hal ini telah memberi peluang kepada murid tersebut untuk mengaitkan atau menggunakan maklumat sejarah yang telah diperolehi untuk diaplikasikan dalam konteks dunia sebenar. Pendapat ini adalah selaras dengan kajian Harris et al (2015) dan Patterson et al (2012) yang telah mempratikkan penggunaan sumber teks sejarah sebagai bahan pengajaran dan pembelajaran bagi meningkatkan kemahiran pemikiran sejarah yang melibatkan penjanaan aras kognitif tinggi dalam kalangan murid. Oleh itu, pemprosesan maklumat daripada pelbagai jenis sumber sejarah secara intensif berupaya untuk mengekalkan kemahiran berfikir aras tinggi dalam kalangan murid (Cerdan, Martin, \& Candel, 2013; Paul, Cerdan, Rouet \& Stadtler, 2018; Reisman \& McGrew, 2018; Shep, Lenihan, McKinley, Plummer \& Dudding, 2017). 
Natijahnya, murid yang menjalani kaedah pengajaran konvensional telah menunjukkan pengekalan penguasaan kemahiran pemikiran sejarah yang lebih rendah berbanding dengan murid yang menjalani pembelajaran berasaskan Multiple Document-based Lessons dan pembelajaran berasaskan Documentbased Lessons. Hal ini disebabkan oleh murid-murid tidak digalakkan untuk menganalisis sumbersumber atau bahan-bahan teks sejarah yang lain yang telah mengehadkan perkembangan proses pemikiran mereka. Pendapat ini adalah konsisten dengan pendapat Nokes (2017) dan Ramoroka dan Engelbrecht (2015) yang menjelaskan bahawa penggunaan buku teks sahaja tidak dapat menggalakkan proses pemikiran aras tinggi dari segi membuat penghujahan dan penjelasan sejarah serta membuat kontekstualisasi terhadap sesuatu peristiwa sejarah yang mengakibatkan proses pemahaman sejarah menjadi terhad kerana murid-murid tidak dapat memahami kepentingan di sebalik sesuatu peristiwa sejarah yang telah berlaku. Oleh hal yang demikian, dapat disimpulkan bahawa pembelajaran berasaskan Multiple Document-based Lessons adalah lebih berkesan terhadap pengekalan penguasaan kemahiran pemikiran sejarah dalam kalangan murid.

\section{Kesimpulan}

Kesimpulannya, pembelajaran sejarah berasaskan Multiple Document-based Lessons merupakan salah satu langkah inovatif pada kaedah pengajaran sejarah yang sedia ada dan didapati berkesan untuk mengekalkan penguasaan kemahiran pemikiran sejarah yang lebih baik dalam kalangan murid berbanding dengan pembelajaran sejarah berasaskan Document-based Lessons dan kaedah pengajaran konvensional. Hal ini demikian kerana murid dapat menguasai dan memahami sesuatu peristiwa sejarah dengan lebih mendalam serta memperolehi suatu gambaran yang menyeluruh terhadap peristiwa sejarah tersebut. Justeru, pelaksanaan pembelajaran sejarah berasaskan Multiple Documentbased Lessons dilihat sebagai suatu langkah positif selaras dengan dasar pendidikan melalui Pelan Pembangunan Pendidikan Malaysia 2013-2025 yang bertujuan untuk melengkapi murid-murid dengan pelbagai kemahiran berfikir secara kritis dan kreatif.

\section{Rujukan}

Abdul Razaq Ahmad. (2014). Determination of teaching aids and methods to inculcate thinking skills in history subjects. TAWARIKH: International Journal for Historical Studies, 6(1), 1-12.

Afferbach, P., \& VanSledright, B. (2001). Hath! Doth! What middle graders reading innovative history text. Journal of Adolescent \& Adult Literacy, 44, 696-707.

Aidinopoulou, V., \& Sampson, D.G. (2017). An action research from implementing flipped classroom model in primary school history teaching and learning. Journal Educational Technology \& Society, 20(1), 237-247.

Atkinson, R.C., \& Shiffrin, R.M (1968). Human memory: A proposed system and its control processes. In K.W. Spence \& J.T. Spence (Eds.), The Psychology of learning and motivation: Advances in research and theory, (vol 2, pp 89-195). New York: Academic Press.

Atkinson, R.C., \& Shiffrin, R.M. (1971). The control of short term memory. Scientific American, 225, $82-90$.

Barton, K.C. (2018). Historical sources in the classroom: Purpose and use. HSSE Online, 7(2), 1-11.

Barton, K.C., \& Levistik, L.S. (2004). Teaching history for the common good. Mahwah, NJ: Erlbaum.

Britt, M.A., \& Rouet, J.F. (2011). Research challenges in the use of multiple documents. International Design Journal, 19(1), 62-68.

Campbell, D.T., \& Stanley, J.C. (1963). Experimental and quasi-experimental designs for Research. Chicago: Rand McNally.

Cerdan, R., Martin M.C., \& Candel, C. (2013). The role of perspective on student use of multiple documents to solve an open ended task. Psicologia Educativa, 19, 89-94.

Cook, T, D., \& Campbell, D.T. (1979). Quasi-experimentation: Design and analysis issues for field settings. Boston: Houghton Mifflin.

Crocker, L., \& Algina, J. (2008). Introduction to classical and modern test theory. USA: Cengage Learning. 
Culminas-Colis, M.V., \& Reyes, W.M. (2016). Teaching historical thinking skills through "reading like a historian" method. The Normal Light, 10(1), 56-77.

Donnelly, D.J. (2018). Contemporary multimodal historical representations and the teaching of disciplinary understandings in history. Journal of International Social Studies, 8(1), 113-132.

Field, A. (2013). Discovering statistics using IBM SPSS statistics. (4 $4^{\text {th }}$ ed). Los Angeles: Sage Publication Inc.

Field, A. (2016). An adventure in statistics: The reality enigma. London: Sage Publications Ltd.

Fitzgerald, J.C. (2009). Textbooks and primary source analysis. Social Studies Research and Practice, $4(8), 37-43$.

Foster, S., \& Crawford, K. (2006). What shall we tell the children? International perspectives on school history textbooks. Greenwich: Information Age.

Gray, C.D., \& Kinnear, P.R. (2012). IBM SPSS statistics 19 made simple. London: Psychology Press.

Green, S.B., \& Salkind, N.J. (2017). Using SPSS for windows and macintosh: Analyzing and understanding data. ( $8^{\text {th }}$ ed.). New York: Pearson.

Greene, J.A., Bolick, C.M., \& Robertson, J. (2010). Fostering historical knowledge and thinking skills using hypermedia learning environments: The role of self-regulated learning. Computer \& Education, 54, 230-243.

Hair, J.F., Black, W.C., Babin, B.J., \& Anderson, R.E. (2014). Multivariate data analysis. (7 ${ }^{\text {th }}$ ed.). Upper Saddle River: Pearson Education.

Harris, L.M., Halvorsen, A.L., \& Aponte-Martinez, G.J. (2015). "[My] family has gone through that': How high school students determine the trustworthiness of historical documents. The Journal of Social Studies Research, 40, 109-121. doi:10.1016/jssr2015.05.007

Hazri Jamil. (2003). Teknik mengajar sejarah. Pahang: PTS Publications \& Distributors Sdn Bhd.

Kaplan, R.M., \& Saccuzzo, D.P. (2009). Psychological testing: Principles, applications and issues $\left(7^{\text {th }}\right.$ ed). Australia: Wadsworth Cengage Learning.

Kaviza, M. (2019). Tahap pengamalan dan penguasaan kemahiran pemikiran sejarah: Perspektif murid berdasarkan empat dimensi gaya pembelajaran. International Journal of Education, Psychology and Counseling, 4(31), 32-45.

Kaviza, M. (2019). Penjanaan Aplikasi Strategi Kemahiran Pemikiran Sejarah Melalui Aktiviti Analisis Sumber-Sumber Dokumen Teks Sejarah: Perspektif Murid Berbeza Tahap Pemikiran Kritis. Malaysian Journal of Social Sciences and Humanities (MJSSH), 4(6), 204-220.

Kaviza, M. (2020). Penggunaan Sumber Dokumen Teks dalam Subjek Sejarah: Satu Sorotan Kajian. Malaysian Journal of Social Sciences and Humanities (MJSSH), 5(10), 200-206.

Kelly, Y.L.K., Kong, S.Q., Song, Y., Deng, L.P., Kang, Y., Hu, A. (2019). What predicts adolescents' critical thinking about real - life news? The roles of social media news consumption and news media literacy.Thinking Skills and Creativity, 1-25.

Kementerian Pendidikan Malaysia. (2013). Pelan Pembanguan Pendidikan Malaysia 2013-2025. Putrajaya: Kementerian Pendidikan Malaysia.

Kobrin, D. (1996). Beyond the textbook: Teaching history using documents and primary sources. Portsmouth, New Hampshire: Heinemann.

Levistik, L. S., \& Barton, K. C. (2011). Doing history: Investigating with children in elementary and middle schools. London: Routledge.

Lezah @ Lejah Kiamsin \& Rosy Talin. (2018). Kaedah pengajaran sejarah yang diminati pelajar dan justifikasinya. Malaysian Journal of Social Sciences and Humanities, 3(2), 137-145.

Ling W, A., Mona Masood, \& Siti Hawa Abdullah. (2016). Analyzing the relationship of sequential and global learning styles on students historical thinking and understanding: A case study on form four secondary schools students in Malaysia. International Journal of Assessment and Evaluation in Education, 6, 50-58.

Linquist, T., \& Long, H. (2011). How can educational technology facilitate student engagement with online primary sources?: A user needs assessment. Library Hi Tech, 29(2), 224-241.

Macedo-Rouet, M., Braasch, J.L.G., Britt, M.A \& Rouet, J.F. (2013). Teaching fourth and fifth graders to evaluate information sources during text comprehension. Cognition and Instruction, 31(2), 204-226.

Merkt, M., Werner, M., \& Wagner, W. (2017). Historical thinking skills and mastery of multiple documents tasks. Learning and Individual Differences, 54, 135-146. 
Neumann, D., Gilbertson, N., \& Hutton, L. (2014). Context: The foundation of close reading of primary source texts. Social Studies Research and Practice, 9(2), 68-76.

Newmann, M. (2001). Primary Sources in perspective. Journal Educations and Students with Library of Congress Resources, 1-10.

Nieuwenhuyse, K.V., Roose, H., Wils, K., Depaepe, F., Verschaffel, L. (2017). Reasoning with and /or about sources? The use of primary sources in Flemish secondary school history education. Journal of Historical consciousness, historical cultures and history education, 4(2), 48-70.

Nokes, J.D. (2014). Elementary students' roles and epistemic stances during document based history lessons. Theory \& Research in Social Education, 42, 375-413.

Nokes, J.D. (2017). Exploring patterns of historical thinking through eight-grade students' argumentative writing. Journal of Writing Research, 8(3), 437-467.

Nokes, J.D., Dole, J.A., \& Hacker, D.J. (2007). Teaching high school students to use heuristics while reading historical texts. Journal of Educational Psychology, 1-14. Nunnally, J.C., \& Bernstein, I.H. (1994). Psychometric theory ( $3^{\text {rd }}$ ed.). New York: McGraw Hill.

Nye, A., Hughes-Warrington, M., Roe, J., Russell, P., Deacon, D., \& Kiem, P. (2011). Exploring historical thinking and agency with undergraduate history students. Studies in higher Education, 36(7), 763-780.

Olwell, R., \& Stevens, A. (2015). "I had to double my thoughts": How to reacting to past methodology impacts first year college student engagement, retention, and historical thinking. The History Teacher, 48(3), 561- 572.

Patterson, N.C., Lucas, A.G., \& Kithinji, M. (2012). Higher order thinking in social studies: An analysis of primary source document use. Social Studies Research and Practice, 7(2), 68-85.

Paul, J., Cerdan, R., Rouet, J.F., \& Stadtler, M. (2018). Exploring fourth grader' sourcing skills. Journal for the Study of Education and Development, 41(3), 536-580.

Pusat Perkembangan Kurikulum. (2003). Huraian sukatan pelajaran mata pelajaran sejarah tingkatan empat. Kuala Lumpur: Kementerian Pendidikan Malaysia.

Pusat Perkembangan Kurikulum. (2013). Dokumen standard kurikulum dan pentaksiran sejarah tahun empat. Putrajaya: Kementerian Pendidikan Malaysia.

Ramoroka, D., \& Engelbrecht, A. (2015). The role of history textbooks in promoting historical thinking in South African classrooms. Yesterday \& Today, 14, 99-124.

Rantala, J., \& Vanden Berg, M. (2015). Finnish high school and university students' ability to handle multiple source documents in history. Journal of Historical Consciousness, Historical Cultures and History Education, 70-88.

Reisman, A. (2012a). Reading like a historian: A document based history curriculum intervention in urban high schools. Cognition and Instruction, 30(1), 86-112.

Reisman, A. (2012b). The "document-based lesson": Bringing disciplinary inquiry into high school history classrooms with adolescent struggling readers. Journal of Curriculum Studies, 44(2), 233264.

Reisman, A., \& McGrew, S. (2018). Reading in history education: Text, sources and evidence. In S.A. Metzger., \& L. M. Harris (Eds.), The Wiley International Handbook of History Teaching and Learning (pp.529-550).

Renuka Ramakrishnan, Norizan Esa \& Siti Hawa Abdullah. (2014, Ogos). Kesan Penggunaan Sumber Sejarah Digital Terhadap Kemahiran Pemikiran Sejarah. Kertas kerja yang dibentangkan di $23^{\text {rd }}$ International Conference of Historians of Asia 2014 (IAHA 2014), Kedah, Malaysia.

Rosy Talin. (2016). Why historical thinking skills was not there? International Journal of Learning, Teaching and Educational Research, 15(3), 134-142.

Rouet-Franqois, J., Favart, M., Britt, M.A., Perfetti, C.A. (1997). Studying and using multiple documents in history: Effects of discipline expertise. Cognition and Instruction, 15(1), 85-106.

Sandwell, R.M. (2008). Using primary documents in social studies and history. The Anthology of Social Studies: Issues and Strategies for Secondary Teacher, 2, 295-307.

Sharp, H., \& Ammert, N. (2017). Primary Sources in Swedish and Australian history textbooks: A comparative analysis of representations of Vietnam's Kim Phuc. International Journal of Historical Learning, Teaching and Research, 4(2), 1-14.

Shep, S.J., Lenihan, R., McKinley, D., Plummer, M., \& Dudding, M. (2017). Moving beyond the threshold: Investigating digital literaties and historical thinking in New Zealand Universities. 
DOI: https://doi.org/10.47405/mjssh.v6i3.724

Practice and Evidence of Scholarship of Teaching and Learning in Higher Education: Special Issue: Threshold Concepts and Conceptual Difficulty, 12(2), 312-332.

Spiro, R., Coulson, R.L., Feltovisch, P.J., \& Anderson, D.C. (1988, Ogos). Cognitive flexibility theory: Advanced knowledge acquisition in ill-structured domains. Kertas kerja yang dibentangkan di $10^{\text {th }}$ Annual Conference of the Cognitive Science, \& Society, Montreal, New Jersey.

Spiro, R.J., \& Jehng, J.C. (1990). Cognitive flexibility and hypertext: Theory and technology for nonlinear and multidimensional traversal of complex subject matter. In D. Nix \& R. J. Spiro (Eds.), Cognition, education and multimedia: exploring ideas in high technology (pp. 163-205). Hillsdale: Lawrence Erlbaum Associates.

Stovel, J.E. (2000). Document Analysis as a tool to strengthen student writing. The History Teacher, 33(4), 501-509.

Stromso, H.I. (2014). Students' sourcing while reading and writing from multiple web documents. Nordic Journal of Digital Literacy, 9, 91-111.

Stromso, H.I., Braten, I., Britt, M.A., \& Ferguson, L.E. (2013). Spontaneous Sourcing among students reading multiple documents. Cognition and Instruction, 31, 176-203.

Uma Sekaran \& Bougie, R. (2013). Research methods for bussiness: A skills-building approach (6 ${ }^{\text {th }}$ ed.). United Kingdom: John Wiley \& Sons Ltd.

Ummadevi Suppiah (2018). Integrated Strategy as Best Practices: Teaching and Learning History. In Halimah Mohd Said, Asma Abdullah, Kalaivani Nadarajah \& Sivachandralingam Sundara Raja (Eds.), History for National Building (pp.122-132). Kuala Lumpur: PCORE.

VanSledright, B. (2002). In search of America's past: Learning to read history in elementary school. New York: Teachers College Press.

Veijola, A., \& Rantala, J. (2018). Assessing Finnish and Californian high school student historical literacy through a document based task. Nordidactica: Journal of Humanities and Social sciences Education, 1, 1-21.

Wiley, J., \& Voss, J.F. (1999). Constructing arguments from multiple sources: Tasks that promote understanding and not just memory for text. Journal of Educational Psychology, 91(2), 301-311.

Wineburg, S. (2001). Historical thinking and other unnatural acts: Charting the future of teaching the past. Philadelphia: Temple University Press. 